\section{5. 日英人のスボーツに対する態度の比校}

京都教育大学○末 利博

研究の目的と概要著者は1956 年在英中，英国の 学生と大学の教官を分類者として 25 個の意見を含さス ポーツに対する態度尺度（1）を作成し，英国人のスポ 一ツに対する態度を調査した（2）. 本研究では英国の調 查対象と対応する日本人群にこれを実施し，両国人のス ポーツに対する愛好度と各意見への反応を分析し，比較 した。 その調查対象は別表の如くである。

研究結果亡その考察両国の調查対象である高校生 - 大学生 成人群の男女別の比较は別表の如くである. 两国の学制のちがいから学生・生徒には幾 分年令のちがいが生じた.この態度尺度へ の反応数では全般的に英国人の方が多くな つた. 別表の Ind. Mean of V の列がそ れを示している.この尺度は 1.4 から 8.4 の尺度值をむつ25個の意見を包含して扣り , 5 点が中庸を，尺度值の低い方がスポー ツ舞好度の高いことを示している. 别表の Mean of Score の列は各群の愛好度の平 均値を示している.これを群別に比較すれ ば，多くの群では両国間に差が認められな からたが，大学生男子では英国の学生が, 高校女子では日本の生徒がそれぞれスポー ツにより愛好的であることを示した．25個 の各意見毎に雨国人の賛成の程度を比校し た場合には，各群ともそれぞれ十個前後の 意見において反応差のあることを示した。
例えば“新聞はスポーツを広告と営利に 利用している” の意見で各群共英国の方が，又“スポーツは人を卒直に する”の意見では日本の方がそれぞれ有意に多くこれ等 に賛成した。前者では両国の社会的条件や生活習慣のち がいが，後者では用語の理解の仕方がそれぞれ反応差の 原因であろらと推測した。

文㙎 1) Study of Attitudes of British Students Towards sports I H. Suetoshi, Bull. of Kyoto Uni. of Education. Ser. B : No. $30,1956$.

2) 同上, I, H. Suetoshi, G. Cooper, 同上 No. 32, 1967.
Comparing Chart of Attitude Scores Between Japanese and British

\begin{tabular}{|c|c|c|c|c|c|c|c|c|}
\hline Group & & $\begin{array}{l}\text { Mean } \\
\text { of Age }\end{array}$ & $\begin{array}{l}\text { No. } \\
\text { of } S\end{array}$ & $\begin{array}{l}\text { No. } \\
\text { of } \mathrm{V}\end{array}$ & $\begin{array}{l}\text { Ind. } \\
\text { Mean } \\
\text { of V }\end{array}$ & $\begin{array}{l}\text { Total } \\
\text { Score }\end{array}$ & $\begin{array}{c}\text { Mean } \\
\text { of } \\
\text { Score }\end{array}$ & $t, p$ \\
\hline $\begin{array}{l}\text { School } \\
\text { Boy }\end{array}$ & $\left|\begin{array}{|l}\mathrm{J} \\
\mathrm{B}\end{array}\right|$ & $\begin{array}{l}17.4 \\
15.6\end{array}$ & $\begin{array}{r}46 \\
100\end{array}$ & $\begin{array}{r}506 \\
1358 \\
\end{array}$ & $\begin{array}{l}11.0 \\
13.6\end{array}$ & $\begin{array}{r}1589.43 \\
4321.04\end{array}$ & $\left|\begin{array}{l}3.159 \\
3.182\end{array}\right|$ & \\
\hline $\begin{array}{l}\text { School } \\
\text { Girl }\end{array}$ & $\mathbf{J}$ & $\begin{array}{l}17.3 \\
15.5\end{array}$ & $\begin{array}{r}52 \\
107\end{array}$ & $\begin{array}{r}583 \\
1414\end{array}$ & $\begin{array}{l}11.2 \\
13.2\end{array}$ & $\begin{array}{l}1817.71 \\
5053.52\end{array}$ & $\begin{array}{l}3.118 \\
3.574\end{array}$ & $\begin{array}{l}t=2,369 \\
0.01<P<0.02\end{array}$ \\
\hline $\begin{array}{l}\text { Adult } \\
\text { Male }\end{array}$ & J & $\begin{array}{l}49.4 \\
45.6 \\
\end{array}$ & $\begin{array}{l}79 \\
75\end{array}$ & $\begin{array}{l}1044 \\
1085 \\
\end{array}$ & $\begin{array}{l}13.2 \\
14.5 \\
\end{array}$ & $\begin{array}{l}3499.04 \\
3592.77 \\
\end{array}$ & $\begin{array}{l}3.352 \\
3.311\end{array}$ & \\
\hline $\begin{array}{l}\text { Adult } \\
\text { Female }\end{array}$ & $\mid \begin{array}{l}\mathrm{J} \\
\mathrm{B}\end{array}$ & $\begin{array}{l}44.4 \\
43.1\end{array}$ & $\begin{array}{l}84 \\
71\end{array}$ & $\begin{array}{l}1101 \\
1036\end{array}$ & $\begin{array}{l}13.1 \\
14.6\end{array}$ & $\begin{array}{l}3665.91 \\
3420.43\end{array}$ & $\begin{array}{l}3.330 \\
3.302\end{array}$ & \\
\hline $\begin{array}{l}\text { Student } \\
\text { Male }\end{array}$ & $\mathbf{J}$ & $\begin{array}{l}19.4 \\
21.6\end{array}$ & $\begin{array}{l}128 \\
127 \\
\end{array}$ & $\begin{array}{l}1360 \\
1750\end{array}$ & $\begin{array}{l}10.6 \\
13.8\end{array}$ & $\begin{array}{l}4957.81 \\
5798.44 \\
\end{array}$ & $\begin{array}{l}3.645 \\
3.313 \\
\end{array}$ & $\begin{array}{l}t=2.146 \\
0.02<P<0.05\end{array}$ \\
\hline $\begin{array}{l}\text { Student } \\
\text { Female }\end{array}$ & {$\left[\begin{array}{l}\mathbf{J} \\
\mathrm{B}\end{array}\right.$} & $\begin{array}{l}18.5 \\
22.8\end{array}$ & $\begin{array}{r}96 \\
177 \\
\end{array}$ & $\begin{array}{l}1068 \\
2388\end{array}$ & $\begin{array}{l}11.1 \\
13.5 \\
\end{array}$ & $\begin{array}{l}3429.67 \\
7819.16 \\
\end{array}$ & $\begin{array}{l}3.211 \\
3.274 \\
\end{array}$ & \\
\hline Total & {$\left[\begin{array}{l}\mathrm{J} \\
\mathrm{B}\end{array}\right.$} & & $\begin{array}{l}485 \\
657\end{array}$ & $\begin{array}{l}5662 \\
9031\end{array}$ & $\begin{array}{l}11.7 \\
13.8\end{array}$ & $\begin{array}{l}18968.57 \\
30005.36\end{array}$ & $\begin{array}{l}3.35 \\
3.32\end{array}$ & \\
\hline
\end{tabular}

\section{6. 大学生の体声に対する瑟度について}

東京大学O岡野 崇彥, 神田 順治
平田 久雄, 小山 秀哉
戸苅 晴壱

体育実技についての分析的研究として，態度の測定 と、スポーツの種目に関する調查を行つた.

方法 対象：東京大学一年生男子 338 名，実施；S42 年5月，態度の測定；25の意見からなる調査表を用いて， リッカート法によつて行つた. スポーツの種目に関する 調査；21 種目のそれぞれについて，過去の経験，興味， 将来の希望を調杏した。

結果 1）態度：全体的には，好意的な 態度得点を示 した. 文科生，理科生による異つた㑯向は認められなか つた．高等学校における運動部経験者と非経験者との比 校は，释験者の方がよく，5\%水準で有意であつた。

大学における運動部所属者と非所属者との比較は, 所 属者の方がよく，5\%水淮で有意であつた，高校，大学 と通じて，部経験者は，体育に対して非経験者より好意 的な態度を持つていることを示した。
2）スボーツの種目に関する調査；態度の 测定による 態度得点の上位，下位それぞれ100名を，好意群，非好 意群として比較した。

過去の経過, 各スポーツ種目の経験の有無は, 野球, テニス，ハンドボール等に $5 \%$ 水淮で有意差がみられた が，全体的に眺めると，二群の間の差は，興味や卒業後 の希望と比較して䫓著なるのではなかつた。

興味（面白そうた）についてみると，サッカー，水 泳，バスケット，ハンドボール，バレーボール，ラグビ 一（以上 $1 \%$ ) スキー, ソフト，野球，柔道（以上 $5 \%$ ） に.二群の間に有意な差を恋めた，比較的動きの激しい と思われる種目については，その差が大きいようであつ た.それに対して、スケート、テニス、コルフ、ボーリ ンク， 弓道等レクリェション的な種目あるいは，なじみ の比較的うすいと思われる種目については，有意な差を 示さなかつた．卒業後の希望；（機会があればぜひやり たい)についてみると，「興味」と同じような㑯向を示 した. 